\title{
Corporate Social Responsibility Performance, Disclosure and Assurance: Introduction to the Special Issue of Administrative Sciences
}

\author{
Isabel-María García-Sánchez ${ }^{1}$ and Jennifer Martínez-Ferrero ${ }^{2, * \mathbb{D}}$ \\ 1 Facultad de Economía y Empresa, Campus Universitario Miguel de Unamuno, Edificio FES, \\ 37006 Salamanca, Spain; lajefa@usal.es \\ 2 Multidisciplinary Institute of Enterprise (MIE), Department of Administration and Business Economics, \\ Universidad de Salamanca, 37008 Salamanca, Spain \\ * Correspondence: jenny_marfe@usal.es
}

Received: 6 September 2018; Accepted: 7 September 2018; Published: 11 September 2018

A threefold impact—social, economic and environmental (Adams and Zutshi 2004)—is achieved via the development of environmental protection systems and policies and via the exercise of actions that promote relations with the society. Consequently, this benefit both the company and the different stakeholders that are affected by it (Adams 2002). It corresponds to the so-called corporate social responsibility (CSR), defined by Heal (2005) as the part of the corporate strategy that responds to inconsistencies between social goals and the search for profitability. In general, CSR describes how firms manage business processes to produce an overall positive impact on society and refer to serving people, communities and the environment in ways that exceed what is legally and financially required of a firm (Jo and Harjoto 2011).

For some years, there has been a consistent belief that traditional financial reports do not adequately represent the different dimensions of corporate activity, resulting in additional non-financial measures of performance (Simnett et al. 2009). This has led companies worldwide to disclose non-financial information, among which it is possible to note the general use of stand-alone reports regarding social and/or environmental concerns, termed sustainability reports. There is an increasing trend to report such performance via the voluntary disclosure (Clarkson et al. 2008) of a sustainability report that assesses the three main components of environmental protection, economic growth and social equity (Morimoto et al. 2005). This voluntary disclosure can be conceived as a viable mechanism through which firm-specific information improves its usefulness and accuracy (Cho et al. 2013). However, there is no regulation that requires the disclosure of this information and companies to publish their sustainability reports voluntarily.

Nonetheless, the considerably growing trend for sustainability reporting in recent decades has not been accompanied by an increase in information credibility and accuracy due to the lack of consistency and completeness of sustainability reports (Adams and Evans 2004). In the context of this lack of credibility, stakeholders demand external assurance (Zorio et al. 2013) as a means of enhancing the degree of confidence in the outcomes of the evaluation of the particular subject matter.

Similarly, to auditing for financial information and as a result of stakeholders' pressure to enhance the credibility of sustainability information, assurance is perceived as the key element in the external scrutiny of the social and/or environmental information issued. Regarding this point, assurance may: (i) provide credibility and transparency of such information (Adams and Evans 2004; O'Dwyer and Owen 2005; Simnett et al. 2009; Weber 2014); (ii) act as a mechanism for increasing the trust of stakeholders not only in the information quality but also in the corporate sustainability commitment (Hodge et al. 2009; Simnett et al. 2009); (iii) act as a monitoring tool of managers (Wong and Millington 2014), since sustainability reporting can address agency relationships; 
and finally (iv) decrease information asymmetry and uncertainty (Moroney et al. 2012). In sum, within a context in which sustainability information is certainly questionable or hardly credible, companies can voluntarily initiate a process of verification of this information. This check will benefit a variety of agents. The company will legitimize the credibility of the information reported by building an effective dialogue with the different stakeholders. To them, meanwhile, external checking guarantees the reliability of the information while reducing the potential information asymmetry existing between managers, shareholders and stakeholders.

Assurance is not a legal requirement and no universal standard for such assurance exists. Indeed, there is substantial heterogeneity in the subject matter of sustainability reports and the objectives, levels and criteria of assurance (Fuhrmann et al. 2016). This leads to differences that make it relevant to study the "who" and "how" in relation to assurance. This heterogeneity in assurance service leads to skepticism concerning an assurer's work because the nature and content of assurance statements can vary significantly (Hodge et al. 2009). Thus, influencing assurance quality.

In this context, the special issue aims to examine, analysis and summarize the main evidence of the corporate social responsibility performance and disclosure, its new trends and the growing assurance market (examining the offer of the sustainability assurance and the possible differences among practitioners). Thus, the three main topics of the special issue are: CSR performance, voluntary disclosure and external assurance.

Regarding the CSR commitment and performance, Amor-Esteban et al. (2018) analyzed the 2004-2014 decade from a panel data sample of 6600 observations from large, 600 internationally listed companies, and based on multivariate statistical methods. They contrasted the relevance of national identity in the sustainable behavior of companies with the discovery of important national discrepancies, which corroborates that the country of origin of companies offers a series of facilities and barriers for the development of CSR practices. Companies, depending on different pressures and expectations, care about what is important in their own country. Thus, the corporations coming from Nordic countries-recognized as welfare states-are presented as the leaders in sustainable behavior, highlighting the social aspect of the proper treatment of their employees and interest groups. They are followed by companies whose country of origin is located in Southern Europe, which priorities environmental reports. Organizations whose headquarters are centralized in North American countries are in a very delayed position, especially in environmental performance, giving greater preference to ethical issues.

Focusing on the second topic of the special issue, the three papers by Oliveira et al. (2018), Bansal et al. (2018) and García-Meca et al. (2018) focused on examining the determinants of CSR disclosure, accounting for firm, industry, ownership and national-level.

Oliveira et al. (2018) analyzed the influence of the characteristics of national business systems on the disclosure of gender-related corporate social responsibility practices by 150 companies in Latin America that signed the Declaration of Support for Women's Empowerment Principles. The highest level of disclosure was related to the establishment of high-level corporate leadership for gender equality. Results showed that the country's level of "concentration of power" and "individualism", and the "orientation towards femininity" had a negative influence on the disclosure of gender-related practices; in addition, the country's level of "economic development" and the "pressure of unions" exerted a positive influence. The results highlight the important role that some national and local institutions play in women's empowerment, leading companies to report information on adopted practices. This study innovates and contributes by introducing an explanation of gender-related social disclosure with the national business system approach in Latin America.

Bansal et al. (2018) examined the impact of board independence on CSR disclosure and analyzed the moderating effect of the presence of family ownership. Using an international sample from 29 countries from 2006 to 2014, their panel Tobit estimation showed that board independence is negatively associated with CSR disclosure practices and they presented in opposition to CSR disclosure practices. However, family ownership moderated the relationship and enforced positive orientation 
of independent directors towards CSR disclosure. This shows that the presence of family ownership reduces independent director concern of reputation risks that are associated with receiving misleading information and that family firms decrease the asymmetries of information between the independent director and management. The study also found that independent directors tend to encourage CSR disclosure in family firms more in civil law countries where investor protection is low compared to common law countries where investor protection is high.

Meanwhile, the paper developed by García-Meca et al. (2018) contribute to the debate on the corporate governance of financial institutions by studying the effect of different board characteristics on the level of CSR disclosures of banks. The authors used a sample composed of 159 banks over the period 2004-2010. They found that independent directors and gender diversity favored the disclosure CSR information in the banking sector. However, these results are moderated by the national cultural system; concretely, previous positive effects of independence and diversity of banks' boards on CSR reporting are reduced in countries with a weaker cultural system, that is, individualist, masculine and vertically stratified societies, that are little indulgent and short-term oriented and show high levels of uncertainty avoidance.

Regarding the assurance of sustainability reports, three papers of the special issue respond to the research call of examining assurance. First, Seguí-Mas et al. (2018), analyzed assurance on corporate governance reports in three Spanish listed companies where they identified the strengths and weaknesses of an unusual assurance process. Due to the recent scandals occurred in the analyzed companies, they raised a particular concern about the potential managerial capture of this activity. Without real changes in governance mechanisms, the corporate governance assurance could amount to little more than a public relations activity.

Second, Ogando et al. (2018) aimed to analyze whether the use of international standards or the profile of the provider performing the service affects the assurance process and quality. To this end, they applied a novel methodology for this field: a survey through written questionnaires. The use of a primary information source allowed them to gain insight into the topic, beyond other visible aspects often used in previous literature (e.g., assurance statement contents). Ogando et al. (2018) again tested their hypotheses on a sample of Spanish accounting and consulting firms. Their results showed that neither the use of international standards nor the provider's professional background had any effect on the assurance process and assurance quality. However, the way the professional perceived the developed service did have an impact on quality.

Meanwhile, the third paper by Sierra-García et al. (2018) on the special issue focused on assurance. Their paper described the presentation of non-financial information reports, analyzing their content and studying levels of compliance with the mandatory disclosure. The study sample allowed them to extrapolate their findings to the pattern that could foreseeably be followed by all listed companies in Spain, since they examined those included in the IBEX-35 index, which is the main national and international reference of the Spanish Stock Exchange and which, in practice, constitutes the asset underlying a large number of financial products. The results revealed that the level of regulatory compliance produced is associated with the business sector in which the company operates. These authors also showed that the highest rates of disclosure of non-financial information correspond to companies that provide this information in the sustainability report.

There are several other contributions of this special issue to prior literature. The main contribution of Amor-Esteban et al. (2018) to the literature is the identification of the virtues and deficiencies in national sustainability systems, which allows recognition of where it is most necessary to an opt or improve CSR practices. Thus, the primary objective of their study was the usefulness of these data as an essential tool for politicians and public managers in the decision-making processes, facilitating the design of more effective policies through knowledge of main concerns and expectations of the countries that lead to a greater CSR commitment.

Oliveira et al. (2018) justified their study by the importance of the subject-of promoting gender equity and empowering women at the local, regional and international levels. It is hoped that the 
knowledge of disclosure about gender issues by Latin American companies may bring new ideas that reflect the influence of political, economic, financial, educational and cultural differences in the countries. Therefore, the study intends to contribute theoretically to the insertion of the NBS approach in investigations on social disclosure and practically by the investigation in a set of companies in Latin America using WEP as the parameter. In the case of Bansal et al. (2018), their study contributes to the existing literature on corporate governance and voluntary disclosure by presenting an in-depth cross-country analysis of the effect of corporate governance on CSR disclosure in general and for family firm in particular. It focuses on the issue of the role of family firms in CSR and its reports, which was not looked at in detail in the existing literature. They also provide new insight into how family firms behave differently from non-family firms in the context of CSR disclosure. The role and effect of corporate governance mechanisms also differ across family and non-family firms.

Meanwhile, García-Meca et al. (2018) clearly contribute to prior literature to research on the corporate governance of financial institutions. Further, this study also adds evidence to the literature on CSR disclosures in the banking sector, which is currently growing. These findings are very relevant due to the impact of financial institutions on the society and the environment. In addition, their study is the first to show the role of the national culture in the banking sector. This suggests that the values, opinions and approaches of individuals regarding CSR affect stakeholders' demands and thus the decisions of the board.

Overall, the papers of Seguí-Mas et al. (2018), Ogando et al. (2018) and Sierra-García et al. (2018), contribute to a growth in scholarship by extending and developing prior research on the topic of assurance services with regard to sustainability reporting (Kolk and Perego 2010; Simnett et al. 2009). This area has just begun to be explored. These papers respond to the call for empirical research about sustainability made by Hasan et al. (2003), but also, they contribute by providing several qualitative research about the assurance demand. In addition, they also follow the recommendation of Kolk and Perego (2010) in examining the quality of sustainability assurance reports, rather than mere adoption. Similarly, they respond to the call of Cohen and Simnett (2014) for studies of assurance quality. They contribute to the limited existing literature concerning the quality of assurance reports.

The findings of this special issue have implications for companies, managers, shareholders, stakeholders and public bodies directly related to the adoption of assurance. First, understanding the reasons for the performance and disclosure of socially responsible commitment and the subsequent assurance is interesting for different information users, such as companies. By doing so, in part, they may legitimize the corporate actions and strategies in the context in which they operate. Furthermore, the evidence provides useful information for investors and stakeholders regarding the CSR commitment of the firm, the minimization of information asymmetries by CSR disclosure and the evaluation of how external assurance increases the credibility about sustainability reporting decreasing so the lack of confidence on it. Moreover, investors should be aware of the use of assurance to enhance credibility and confidence about sustainability information as a signal for future investment decisions. In any case, assurance may add value for shareholders and stakeholders by showing the managerial commitment to reporting credible sustainability information. For policy markets and regulatory organisms, the findings may be informative given the increased of CSR reporting and assurance demand. Understanding the CSR performance, disclosure and assurance differences, difficulties or quality, to a lesser extent can help them to determine the areas of deficiencies in these issues. For example, they could collaborate with companies in the promotion of institutional support programmes to ensure the quality and assurance of sustainability reports. Public authorities must be able to provide new national laws and requirements, legislative reforms, institutional programmes or financial support in influencing increased CSR performance, disclosure and assurance, which adds value to organizations without costly regulation. Moreover, in general, the disclosure and assurance practice is unregulated and non-standardized given the absence of regulatory laws. Thus, the findings of this special issue show that it should be in the interests of governments, policymakers and public institutions to provide institutional support for the CSR policy (performance, disclosure and assurance). 
Funding: The authors wish to acknowledge the financial support from the Ministry of Science and Innovation for the research project ECO2013-43838P and from the DISAQ project funded by the University of Salamanca. Any errors included in this paper are sole responsibility of the authors.

Conflicts of Interest: The authors declare no conflicts of interest.

\section{References}

Adams, Carol A. 2002. Internal organisational factors influencing corporate social and ethical reporting: Beyond current theorising. Accounting, Auditing \& Accountability Journal 15: 223-50.

Adams, Carol A., and Richard Evans. 2004. Accountability, completeness, credibility and the audit expectations gap. Journal of Corporate Citizenship 14: 97-115. [CrossRef]

Adams, Carol, and Ambika Zutshi. 2004. Corporate social responsibility: Why business should act responsibly and be accountable. Australian Accounting Review 14: 31-39. [CrossRef]

Amor-Esteban, Víctor, Ma-Purificación Galindo-Villardón, and Fátima David. 2018. Study of the Importance of National Identity in the Development of Corporate Social Responsibility Practices: A Multivariate Vision. Administrative Sciences 8: 50. [CrossRef]

Bansal, Shashank, Maria Lopez-Perez, and Lazaro Rodriguez-Ariza. 2018. Board Independence and Corporate Social Responsibility Disclosure: The Mediating Role of the Presence of Family Ownership. Administrative Sciences 8: 33. [CrossRef]

Cho, Seong Y., Cheol Lee, and Ray J. Pfeiffer Jr. 2013. Corporate social responsibility performance and information asymmetry. Journal of Accounting and Public Policy 32: 71-83. [CrossRef]

Clarkson, Peter M., Yue Li, Gordon D. Richardson, and Florin P. Vasvari. 2008. Revisiting the relation between environmental performance and environmental disclosure: An empirical analysis. Accounting, Organizations and Society 33: 303-27. [CrossRef]

Cohen, Jeffrey R., and Roger Simnett. 2014. CSR and assurance services: A research agenda. Auditing: A Journal of Practice \& Theory 34: 59-74.

Fuhrmann, Stephan, Christian Ott, Elisabeth Looks, and Thomas W. Guenther. 2016. The Contents of Assurance Statements of Sustainability Reports and Information Asymmetry. Accounting and Business Research 47: 369-400. [CrossRef]

García-Meca, Emma, María-Victoria Uribe-Bohórquez, and Beatriz Cuadrado-Ballesteros. 2018. Culture, Board Composition and Corporate Social Reporting in the Banking Sector. Administrative Sciences 8: 41. [CrossRef]

Hasan, Mahreen, Peter J. Roebuck, and Roger Simnett. 2003. An investigation of alternative report formats for communicating moderate levels of assurance. Auditing: A Journal of Practice $\mathcal{E}$ Theory 22: 171-87.

Heal, Geoffrey. 2005. Corporate social responsibility: An economic and financial framework. The Geneva Papers on Risk and Insurance-Issues and Practice 30: 387-409. [CrossRef]

Hodge, Kristy, Nava Subramaniam, and Jenny Stewart. 2009. Assurance of sustainability reports: Impact on report users' confidence and perceptions of information credibility. Australian Accounting Review 19: 178-94. [CrossRef]

Jo, Hoje, and Maretno A. Harjoto. 2011. Corporate governance and firm value: The impact of corporate social responsibility. Journal of Business Ethics 103: 351-83. [CrossRef]

Kolk, Ans, and Paolo Perego. 2010. Determinants of the adoption of sustainability assurance statements: An international investigation. Business Strategy and the Environment 18: 182-98. [CrossRef]

Morimoto, Risako, John Ash, and Chris Hope. 2005. Corporate social responsibility audit: From theory to practice. Journal of Business Ethics 62: 315-25. [CrossRef]

Moroney, Robyn, Carolyn Windsor, and Yong Ting Aw. 2012. Evidence of assurance enhancing the quality of voluntary environmental disclosures: An empirical analysis. Accounting E Finance 52: 903-39.

O'Dwyer, Brendan, and David L. Owen. 2005. Assurance statement practice in environmental, social and sustainability reporting: A critical evaluation. The British Accounting Review 37: 205-29. [CrossRef]

Ogando, Natalia Vaz, Silvia Ruiz Blanco, and Belen Fernandez-Feijoo. 2018. A Provider's Approach to the Assurance Market of Sustainability Reports in Spain. Administrative Sciences 8: 28. [CrossRef] 
Oliveira, Marcelle Colares, Manuel Salgueiro Rodrigues Júnior, Sérgio Henrique de Oliveira Lima, and George Alberto de Freitas. 2018. The Influence of the Characteristics of the National Business System in the Disclosure of Gender-Related Corporate Social Responsibility Practices. Administrative Sciences 8: 14. [CrossRef]

Seguí-Mas, Elies, Helena-María Bollas-Araya, and Fernando Polo-Garrido. 2018. Assurance on Corporate Governance Reports in Spain: Towards an Enhanced Accountability or a New Form of Public Relations? Administrative Sciences 8: 32. [CrossRef]

Sierra-García, Laura, Maria Garcia-Benau, and Helena Bollas-Araya. 2018. Empirical Analysis of Non-Financial Reporting by Spanish Companies. Administrative Sciences 8: 29. [CrossRef]

Simnett, Roger, Ann Vanstraelen, and Wai Fong Chua. 2009. Assurance on sustainability reports: An international comparison. Accounting Review 84: 937-67. [CrossRef]

Weber, Jessica Lee. 2014. Corporate Social Responsibility Disclosure Level, External Assurance and Cost of Equity Capital. External Assurance and Cost of Equity Capital. Ph.D. Thesis, University of Colorado Boulder, Boulder, CO, USA, December 16.

Wong, Renfred, and Andrew Millington. 2014. Corporate social disclosures: A user perspective on assurance. Accounting, Auditing \& Accountability Journal 27: 863-87.

Zorio, Ana, Maria A. García-Benau, and Laura Sierra. 2013. Sustainability development and the quality of assurance report: Empirical evidence. Business Strategy and the Environment 22: 484-500. [CrossRef]

(C) 2018 by the authors. Licensee MDPI, Basel, Switzerland. This article is an open access article distributed under the terms and conditions of the Creative Commons Attribution (CC BY) license (http://creativecommons.org/licenses/by/4.0/). 